\title{
Erosión controlada en tubos de asbesto-cemento conductores de agua potable
}

\section{Contrclled erosion in asbestos-cement pipe used in drinking water distribution systems}

\author{
MARIANA RAMOS P. \\ Departamento de Ciencia e Ingenieria de Materiales (IDIEM) \\ Universidad de Chile \\ Fecha de recepción: 26-IV-1990 \\ Casilla 1420, Santiago, Chile
}

\section{RESUMEN}

Se sometió a dos tratamientos erosivos controlados uno por agitación (300 rpm, $60 \mathrm{~min}$ ) y otro por ultrasonido (47 kHz, $30 \mathrm{~min}$.) a muestras de tubos de asbesto cemento, sumergidas en agua destilada, usados para el trasporte de agua potable. Con SEM se observó la morfología de muestras de tubos sin uso, con y sin tratamiento erosivo y la de muestras extraídas de tubos de asbesto cemento de la red de distribución de agua potable de la ciudad de Santiago con 10 y 14 años de servicio. Con TEM se determinó la concentración de fibras de asbesto en el agua de ensayo: 365 MFL y 1690 MFL (millones de fibras por litro) en agitación y ultrasonido, respectivamente. Se estimó en 4 y 10 años de servicio equivalente los tratamientos erosivos de agitación y ultrasonido, respectivamente en tubos de asbesto cemento empleados en la red de agua potable.

\begin{abstract}
Samples of asbestos-cement pipe used for drinking water conveyance, were submerged in distilled water, and subjected to two controlled erosive treatments, namely agitation (300 rpm for $60 \mathrm{~min}$ ) and ultrasound $(47 \mathrm{kHz}$ for $30 \mathrm{~min}$ ). SEM was used to observe and compare the morphology of the new pipe with and without erosive treatment, and of samples taken from asbestos-cement pipes used in the distribution system of drinking water in Santiago city for 10 and 40-years of service. TEM was used to determine the concentration of asbestos fibers in the test water: $365 \mathrm{MFL}$ and $1690 \mathrm{MFL}$ (millions of fibers per litre) as an agitation and result ultrasound, respectively. The erosive treatments by means of agitation or ultrasound applied to new asbestos-cement pipes used in the drinking water distribution system were evaluated as being equivalent to 4 and 10 years of service, respectively.
\end{abstract}

\section{INTRODUCCIÓN}

El interés por estudiar la presencia de asbesto en el agua comenzó en la década del $70(1,2)$, debido al riesgo potencial que presenta la ingestión de fibras en enfermedades gastrointestinales y en el desarrollo de tumores malignos (3-6). Estos trabajos se centraron en determinar la presencia y concentraciones de fibras de asbesto en todas aquellas sustancias que pudieran ser ingeridas por el hombre, encontrándose que el agua era el factor más importante en el consumo promedio de fibras (7). Se evaluó el contenido de fibras en nieves derretidas, aguas de lagos, aguas de ríos,

(*) Por ausencia del IDIEM de M. Ramos toda correspondencia dirigirla a G. Díaz, Universidad de Chile, Casilla 1420, Santiago, Chile.

\section{INTRODUCTION}

The interest for studying the presence of asbestos in water started in the 1970s $(1,2)$ owing to the potential risk of fiber ingestion as concerns gastrointestinal deseases and the development of malignant tumors (3-6). These works were carried out to ascertain the presence and concentration of asbestos fibers in all those substances that might be ingested by man, and they found that water was the most imprtant factor in the average consumption of fibers (7). Fiber contents were appraised in melted snows, in lake and river waters, in distribution systems of drinking water, thus detecting concentrations in the

(*) On leave of the IDIEM, all correspondance must be send to G. Diaz, Universidad de Chile, Casilla 1420, Santiago, Chile. 
sistemas de agua potable, encontrándose concentraciones de 0,003 a 113 millones de fibras por litro (MFL) en zonas sin polución y en zonas poluídas, respectivamente $(2,8)$. Las fibras de asbesto se encuentran en el agua por diferentes causas; arrastre de fibras por el viento desde zonas poluidas de asbesto a los cauces de aguas, erosión de las rocas y suelos que contengan estos minerales, contaminación por actividades industriales, desprendimiento de las fibras de los conductos o tubos de asbesto-cemento, usados en las redes de distribución de agua potable, etc., (9). La naturaleza corrosiva del agua blanda y la erosión mecánica deterioran la matriz de cemento, dejando al descubierto las fibras de asbesto y quedando expuestas a ser arrastradas por el agua. Se han realizado varios estudios con el objeto de evaluar la erosión pero las dificultades de realizar dichas investigaciones agravadas por la gran dispersión de los resultados impiden la obtención de modelos representativos $(9,10)$.

El objetivo de este trabajo fue someter a una erosión controlada a tubos de

asbesto-cemento sin uso, empleados para la distribución de agua potable, sumergiendo trozos de ellos en agua y aplicando luego tratamientos de ultrasonido y agitación. Los efectos producidos por ambos tratamientos erosivos se compararon con la corrosión observada en tubos extraidos de las redes de distribución de agua potable de la ciudad de Santiago que tenian 10 y 40 años de servicio. Las superficies de los tubos se observaron con SEM (Scanning Electron Microscopy) y con TEM (Transmission Electron Microscopy) se caracterizó y cuantificó las fibras de asbesto $(4,6,7,11)$.

\section{Procedimiento Experimental}

Las muestras se obtuvieron de tubos de asbesto-cemento comercial sin uso de 0,150 , 0,100 y $0,050 \mathrm{~m}$ de diámetro con un espesor de $0,014 \mathrm{~m}, 0,012 \mathrm{~m}$ y $0,010 \mathrm{~m}$ respectivamente y de tubos en servicio por 10 y 40 años extraidos de las redes de distribución de agua potable. De los tubos sin uso se cortaron trozos de $0,015 \times 0,020 \mathrm{~m}$ y se impregnaron con resina epoxi dejando sin cubrir un área de $1 \mathrm{~cm}^{2}$ de la cara interna del tubo. Las muestras así preparadas se sumergieron en $100 \mathrm{~cm}^{3}$ de agua destilada, libre de asbesto, con un índice de agresividad igual a 6,24, clasificada como altamente agresiva por la American Water Works Association A.W.W.A. $(6,9)$. Un grupo de 12 muestras de tubos sin uso sumergidas en agua se sometió a un tratamiento erosivo por ultrasonido $(47 \mathrm{kHz})$ durante 30 minutos y un segundo grupo de 12 muestras se sometió a range from 0.003 to 113 million fibers per litre (MFL) in unpolluted and in polluted zones, respectively $(2,8)$. Asbestos fibers are to be found in water for a number reasons, namely: through fiber transport by the wind from zones having asbestos pollution to water streams, through erosion of rocks and soils containing these minerals, through industrial contamination, through the release of fibers from asbestos-cement pipes used in the distribution of drinking water, etc. (9). The corrosive action of soft water and the mechanical erosion damages the cement matrix and uncover asbestos fibers, which may then be washed out by water. Several studies have been conducted in order to evaluate such erosion, but the difficulties that are encountered in these investigations, aggravated by the large dispersion of the results, are hindering the obtainment of representative models $(9,10)$.

The aim of the present work was to apply a controlled rate of erosion to new asbestos-cement pipe used for drinking water distribution; by submerging pieces thereof in water and then treating them by means of ultrasound and agitation. The effects of both erosive treatments were compared to corrosion abserved in pipes removed from Santiago city's drinking water distribution systems that had been in service for 10 to 40 years. Pipe surfaces were observed by means of SEM (Scanning Electron Microscopy); TEM (Transmission Electron Microscopy) was used to characterise and count asbestos fibers $(4,6,7,11)$.

\section{Experimental Procedure}

The samples were taken from new asbestos-cement pipes $0.150 \mathrm{~m} ; 0.100 \mathrm{~m}$ and $0.050 \mathrm{~m}$ in diameter having thicknes of $0.014 \mathrm{~m}, 0.012 \mathrm{~m}$ and $0.010 \mathrm{~m}$, respectively, and from asbestos-cement pipes of drinking-water distribution systems in service for 10 and 40 years. The new pipes were cut into pieces measuring $0.015 \times 0.020 \mathrm{~m}$ and were impregnated with epoxy resin so as to leave uncovered an area of $1 \mathrm{~cm}^{2}$ of the inner face of the pipe. The samples thus prepared were submerged in $100 \mathrm{~cm}^{3}$ of distilled water free of asbestos, exhibiting an aggresive index equal to 6.24 , which is classified as highly aggessive by the American Water Works Association, AWWA $(6,9)$. A group of 12 samples of new pipes submerged in water, was subjected to an erosive treatment through ultrasound $(47 \mathrm{kHz})$ for 30 minutes, and a second group of 12 samples was subjected to 
un tratamiento erosivo por agitación del agua por medio de una aspa (300 rpm) durante 60 minutos. Las superficies de las muestras con tratamiento erosivo y de muestras de tubos en servicio se observaron con SEM. La cuantificación de las fibras de asbesto se hizo con TEM, para lo cual se usó el Nucleoporo de filtro doble. Se tomaron $0,05 \mathrm{~cm}^{3}$ del agua tratada de cada muestra y se depositó sobre una malla de cobre de $0,03 \mathrm{~m}$ de diámetro, 200 mallas, abertura de malla $6,68 \times 10^{-6} \mathrm{~cm}^{2}$, con película soporte de Formvar, luego se eliminó el líquido secando con luz infrarroja. El contraste se mejoró evaporando carbón sobre la malla. Los tubos de asbesto-cemento usados comúnmente en la distribución de agua potable, en la ciudad de Santiago, contienen una mezcla de $20 \%$ de fibras de asbesto chrysotilo y crocidolita y de $80 \%$ de cemento portland.

\section{Resultandos y Discusión}

En la observación y cuantificación de las fibras de asbesto, no se aprecia una variación significativa entre los distintos diámetros de los tubos sometidos a tratamiento erosivo. Este hecho se debe probablemente a que las condiciones de fabricación son similares a todos los tubos, de manera que el tipo y porcentaje de fibras comunes les confiere iguales características. En la serie de micrografías (Fig. 1 a Fig. 5) se pueden

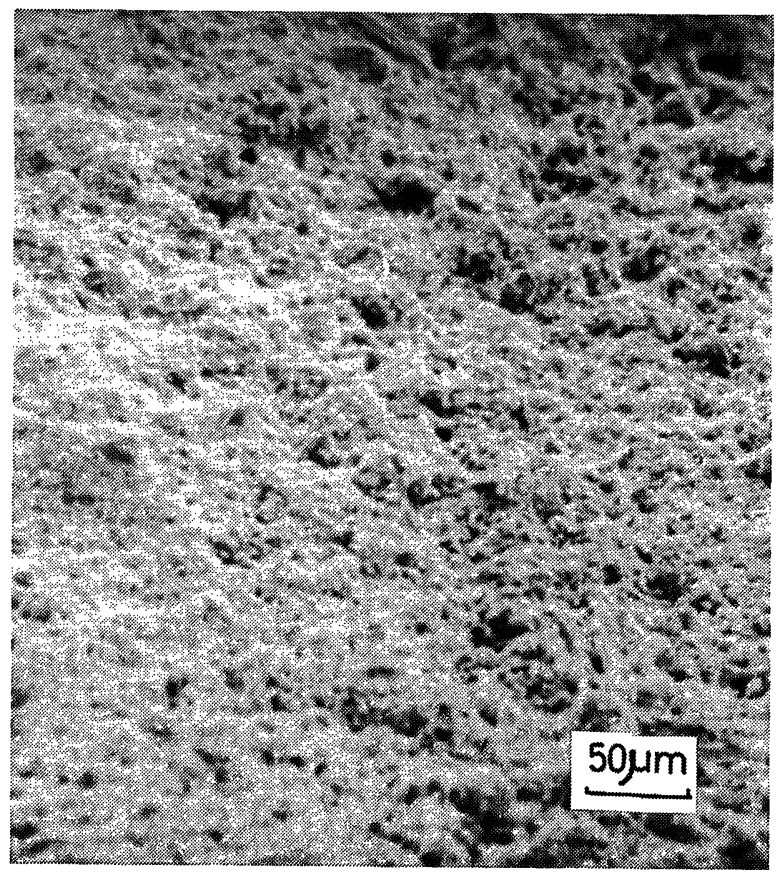

Fig. 1.- Tubo nuevo sin tratamiento. Vista general en la que se observa la rugosidad de la superficie.

Fig. 1.-New Pipe, Untreated. Overall View Showing Surface Roughness. an erosive treatment through agitation in water by means of a rotating blade (300 rpm) for 60 minutes. The surfaces of the samples subjected to the erosive treatment and of the samples taken from the pipes in service, were observed using SEM. Fiber count was carried out by means of TEM using the double Nuclepore filter technique (11). To this end $0.05 \mathrm{~cm}^{3}$ of the treated water of each sample was deposited on a 200-mesh copper grid $0.003 \mathrm{~m}$ in diameter, with $6.68 \times 10^{-6} \mathrm{~cm}^{2}$ openings and Formvar support film, and thereafter the liquid was removed through infrared-light drying. The contrast was improved by evaporating carbon on the grid. Asbestos-cement pipes employed in the distribution of drinking water in Santiago city, usually contain a mixture that comprises $20 \%$ of chrysotile and crocidolite asbestos fibers, and $80 \%$ of portland cement.

\section{Results and Discussion}

The morphological and quantitative observations of asbestos fibers do not show any significant variation between the different diameters of the pipes subjected to the erosive treatments. This is probably due to the fact that manufacturing conditions are similar for all the pipes, so that the type and percentage of common fibers are imparting like characteristics to all of them. The micrograph series shown in Figs. 1 to 5 illustrates the most

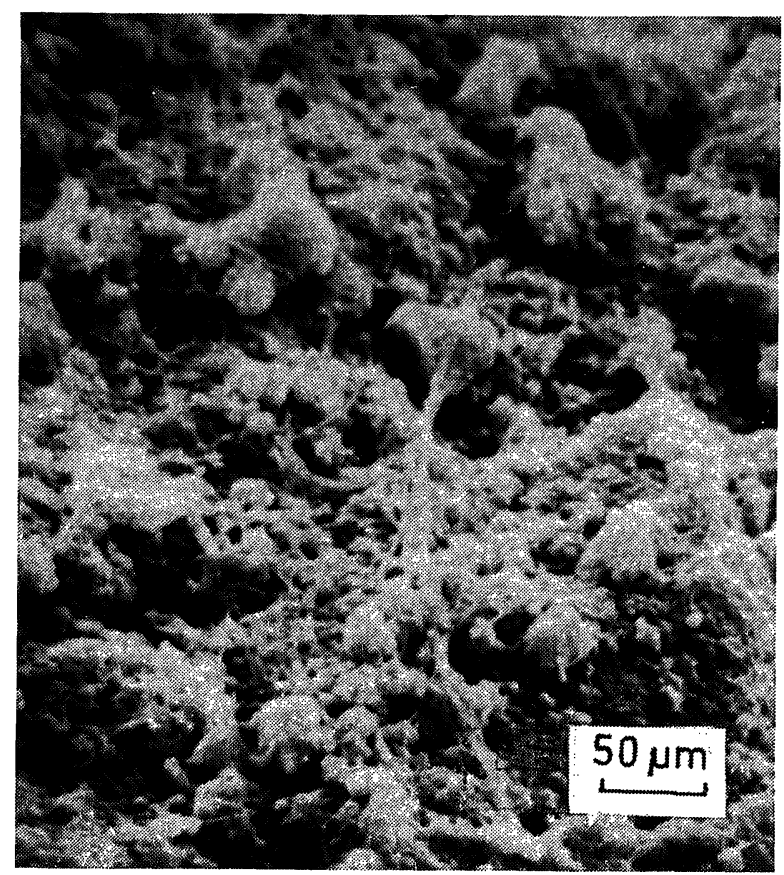

Fig. 2.-Tubo nuevo ensayado durante $60 \mathrm{~min}$., con agitación. Se aprecian fibras sueltas en la superficie.

Fig. 2.-New Pipe Subjected to 60-min Agitation Testing. Loose Fibers Appear on Pipe Surface. 


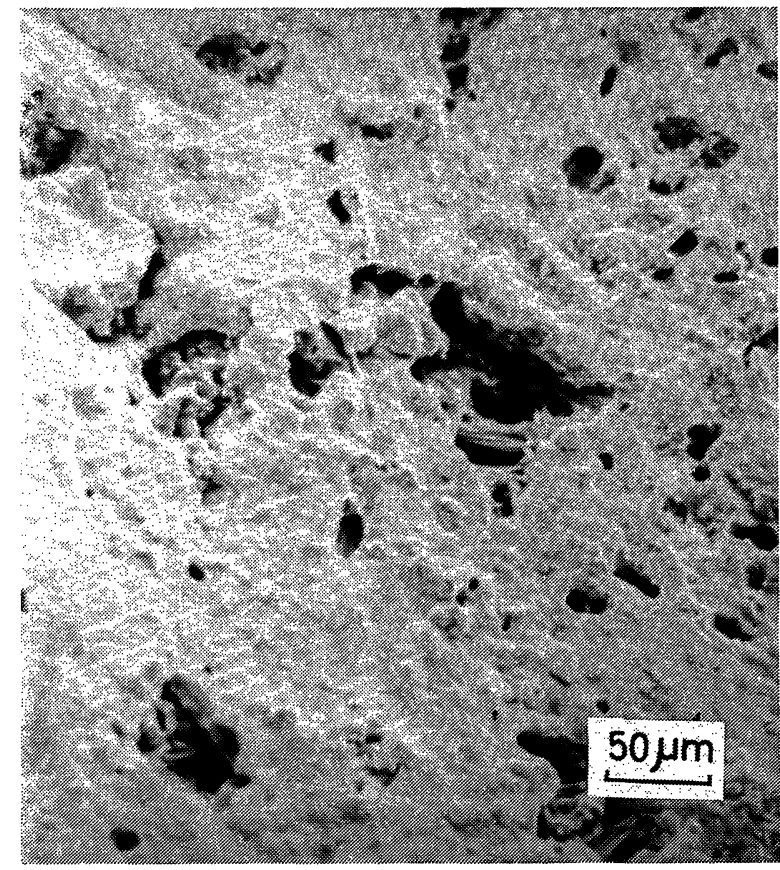

Fig. 3.-Tubo nuevo ensayado durante $30 \mathrm{~min}$., con ultrasonido. Superficie erosionada en la que se aprecian numerosas cavidades.

Fig. 3.-New Pipe Subjected to 30-min Ultrasound Testing. Many Cavities Appear on Eroded Surface.

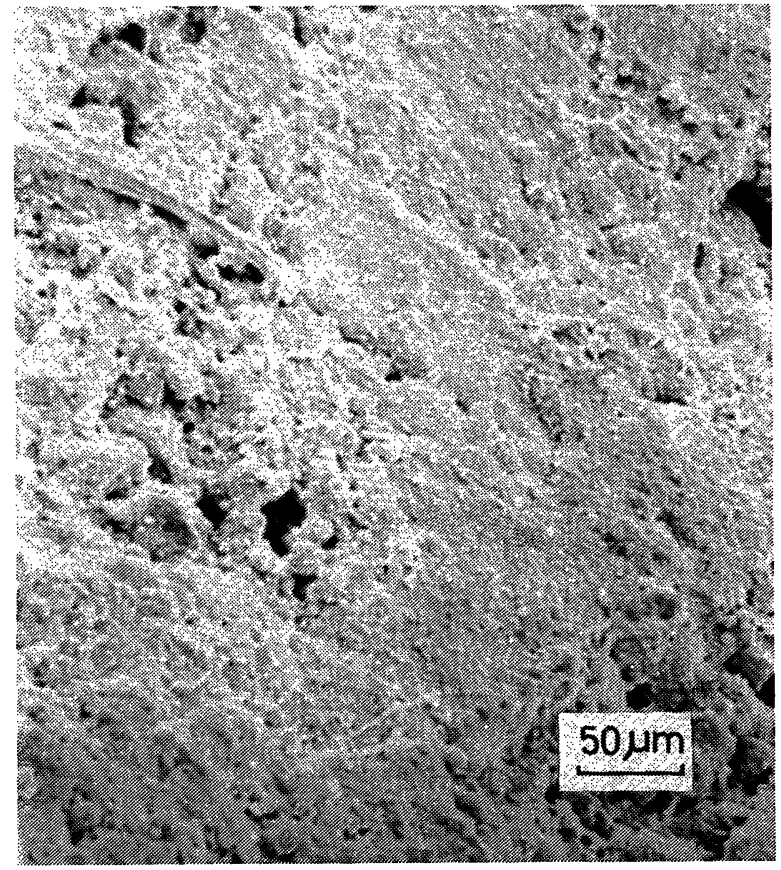

Fig. 4.-Tubo en servicio 10 años. Superficie lisa y cavidades.

Fig. 4.-Pipe in Service for 10 Years. Smooth Pipe Surface and Cavities are Visible.

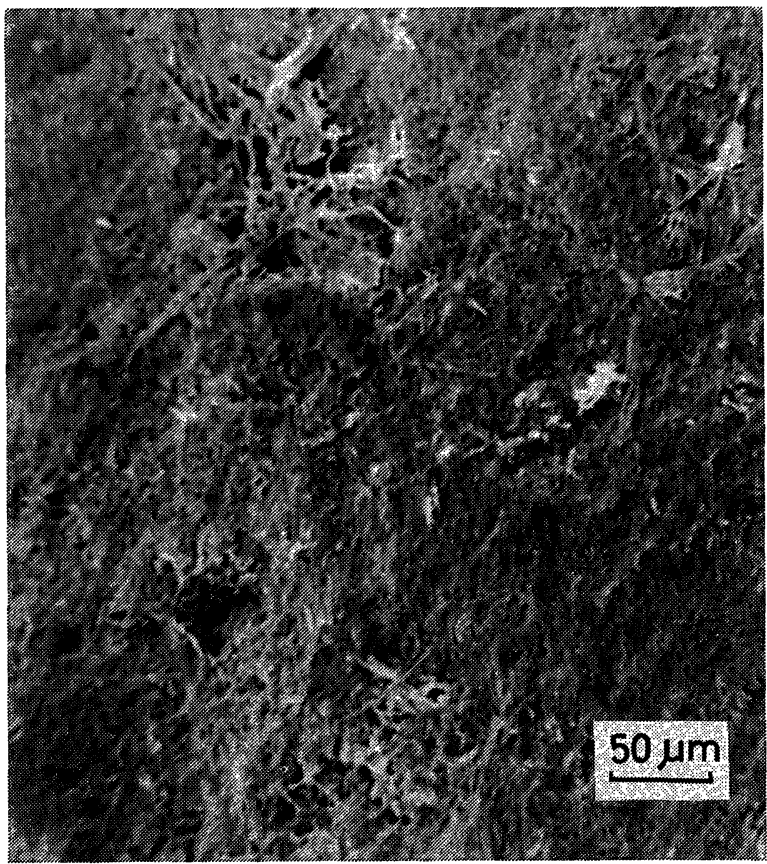

Fig. 5.-Tubo en servicio 40 años. Zonas erosionadas con fibras sueltas.

Fig. 5.-Pipe in Service for 40 Years. Eroded Zones with Loose Fibers are Visible.

apreciar las superficies más representativas de los tubos sin uso, sin tratamiento y con tratamiento erosivo, así como los tubos en servicio durante 4 y 10 años. representative surfaces of the new pipes, either untreated or subjected to the erosive treatment, as well as the pipes after 10 or 40-years service.

MATERIALES DE CONSTRUCCION, Vol. 40, n.²18, abril/mayo/junio 1990 
En los tubos sin uso no sometidos a tratamientos erosivos la superficie de la cara interna de los tubos estaba rugosa y continua, la mezcla de cemento y fibras de asbesto era homogénea y las fibras de asbestos visibles estaban entrelazadas a la matriz de cemento (Fig. 1).

Las superficies de las muestras de tubos sin uso sometidas a erosión por agitación durante 60 minutos, presentan un aspecto similar a las de los tubos sin uso y sin tratamiento, pero se observan ciertos sectores erosionados, el inicio de algunas cavidades, las fibras de asbesto están más a la vista y se aprecian también fragmentos de la matriz (Fig. 2). Las muestras de tubos sin uso sometidas a erosión por ultrasonido durante 30 minutos, presentan una superficie diferente, más bien lisa pero con cavidades bien definidas. En los huecos producidos por la erosión se pueden observar además fibras libres de cemento (Fig. 3).

Tubos en servicio durante 10 años, presentan una superficie lisa con sectores de erosión localizados y se encuentran algunos paquetes de fibras que emergen de la matriz de cemento (Fig. 4). Tubos en servicio durante 40 años también muestran una superficie muy lisa con una mayor proporción de paquetes de fibras, las cuales se observan disgregadas y sueltas (Fig. 5).

Con TEM se contabilizó el número de fibras de asbesto presentes en una abertura de malla y se determinó a continuación en millones de fibras por litro, MFL, la concentración de fibras de asbesto para cada uno de los tratamientos erosivos usando la fórmula propuesta por Millette and Mc Farren (12). Para el tratamiento de agitación se obtuvo un promedio de 3 fibras de asbesto por abertura de malla, en consecuencia la concentración de fibras fue de $635 \mathrm{MFL}$. En tanto que para el tratamiento de ultrasonido se obtuvo un promedio de 8 fibras de asbesto por abertura de malla y por lo tanto la concentración de fibras fue de 1690 MFL. Luego el tratamiento erosivo por ultrasonido resultó ser cinco veces más severo. Las dimensiones medias de las fibras liberadas fue $55 \mu \mathrm{m}$ de longitud y $6 \mu \mathrm{m}$ de diámetro, las que no resultaron afectadas ni destruidas por ninguno de los tratamientos erosivos (13).

De acuerdo con numerosas observaciones con SEM a las muestras de tubos de asbesto-cemento con y sin tratamiento erosivo apreciando el aspecto superficial que presentan y comparando con tubos extraidos de las redes de distribución de agua potable es posible estimar que el tratamiento erosivo por agitación corresponde a un tiempo de
In the new pipes without erosive treatment the inner face was rough and continuous, the mixture of cement and asbestos fibers was homogeneous, and the visible asbestos fibers were interlocked with the cement matrix, as can be observed in Fig. 1.

The surfaces of the new pipe samples subjected to erosion through $60 \mathrm{~min}$ agitation are exhibiting an appearance similar to that of the untreated new pipes, but there can be seen certain eroded areas, the formation of some cavities, the greater visibility of asbestos fibers, and some matrix fragments, as in Fig. 2. On the other hand, the new pipe samples subjected to erosion through $30 \mathrm{~min}$ ultrasound exhibit a different surface morphology rather smooth but with well-defined cavities. In addition cement-free fibers can be seen in the voids produced by the erosion, as in Fig. 3.

The pipes in service for 10 years (Fig. 4) exhibit a smooth surface with localised eroded areas, and some fiber bundles are emerging from the cement matrix. As to the pipes in service for 40 years (Fig. 5), they also exhibit a very smooth surface with a larger proportion of bundles, whose fibers are disgregated and loose.

TEM was used to count the number of asbestos fibers present in one grid opening, and thereafter the asbestos fiber concentration in MFL (millions of fibers per litre) was ascertained for each one of the erosive treatments using the formula proposed by Millette and McFarren (12). The agitation treatment yielded and average of 3 asbstos fibers per grid opening and thus fiber concentration amounted to 635 MFL. On the other hand the ultrasound treatment yielded an average of 8 asbestos fibers per grid opening and thus fiber concentration was to $1690 \mathrm{MFL}$ in this instance. Hence the ultrasound erosive treatment proved to be five times more severe. The fibers set free averaged $55 \mu \mathrm{m}$ in length and $6 \mu \mathrm{m}$ in diameter, and these dimensions were neither affected nor destructed by any of the erosive treatments (13).

Many asbestos-cement samples treated and untreated were observed by means of SEM in order to ascertain their surface appearance and to compare them with pipes taken from drinking water distribution systems. These observations allowed us to deduce that the corrosive treatment with agitation is corresponding to a 4-year service time 
servicio de cuatro años, mientras que el tratamiento erosivo por ultrasonido corresponde a un tiempo de servicio de diez años. La metodología empleada permitiría obtener datos representativos del fenómeno de erosión de tubos de asbesto-cemento, conductores de agua potable, con las cuales investigar el mecanismo de contribución de fibras de asbesto en el agua provenientes de tales tubos.

\section{CONCLUSIONES}

Con los tratamientos empleados en tubos de asbesto-cemento usados en el transporte de agua potable se erosiona la matriz de cemento, el que es arrastrado por el agua, dejando libres a las fibras de asbesto las que a su vez ingresan al agua potable. La observación micrográfica, SEM, muestra una disminución de rugosidad de los tubos sin uso, mayor tamaño de cavidades en la matriz de cemento y presencia de fibras de asbesto libres de cemento. La concentración de fibras de asbesto determinada con TEM fue de 635 MFL y 1690 MFL para muestras sometidas a los tratamientos erosivos por agitación y ultrasonido, respectivamente, donde este último resultó cinco veces más drástico que el primero. También con SEM se estima en 4 y 10 años el tiempo de servicio equivalente que correspondería a los tratamientos de agitación y ultrasonido, respectivamente, en tubos de asbesto-cemento usados en la red de agua potable.

\section{AGRADECIMIENTOS}

El autor desea agradecer al Instituto de Investigaciones y Ensayos de Materiales (IDIEM) por las facilidades dispuestas para esta investigación. whereas the treatment with ultrasound is corresponding to a 10-year service time. The methodology employed would allow one to obtain representative data regarding erosion phenomena in asbestos-cement pipe used in drinking water distribution systems, and these data would serve to investigate the mechanism govering asbestos-cement fiber contribution to water conveyed through such water supply pipes.

\section{CONCLUSION}

The laboratory treatments applied to asbestos-cement pipe used for drinking water conveyance produce a gradual erosion of the cement matrix, which is carried away by water, thus setting free asbestos fibers which are dispersed in drinking water. Micrographic inspection using SEM is showing surface roughness reduction in new pipes, larger cavities in the cement matrix, and the presence of loose asbestos fibers free of cement. Asbestos fiber concentration amounted to 635 MFL and 1690 MFL according to TEM, for the samples eroded through agitation and through ultrasound, respectively. Thus ultrasound erosion proved to be five times more severe than erosion resulting from agitation. In addition, SEM allows to determine that 4 and 10 years would be the equivalent times of service corresponding to the agitation and to the ultrasound respectively, of asbestos treatment cement pipe used in drinking water distribution systems.

\section{ACKNOWLEDGEMENTS}

The authoress would like to thank the Departamento de Ciencia e Ingeniería de Materiales (IDIEM) for the facilities provided in order to allow the carrying out of the present investigation. Thanks are also to Raymond Toledo for his helps with the manuscript.

\section{REFERENCIAS}

\section{(REFERENCES)}

(1) R. L. ZIELHUIS: Commission of European Communities, "Public Healt Risks of Exposure to Asbestos", Pergamon Press, Great Britain (1977)

(2) J. H. KAY: "Ontario Intesifies Search for Asbestos in Drinking Water", Water Pollution Contribution, 83 (1973)

(3) K. J. PATEL-MANDLINK, J. R. MILLETE: Proc. Scanning Electr. Micr., vol. I., 3474 (1980).

(4) J. R. MILLETTE and P. J. CLARK: Proc. Scanning Electr. Micr., vol. I, 253 (1978).

(5) S. V. NICOSIA and J. H. JOHNSON: Proc. Scanning Electr. Micr., vol. III, 1329 (1984).

(6) P. J. CLARK, J. R. MILLETTE and R. L. BOONE: Proc. Scanning Electr. Micr., vol. I, 3417 (1980).

(7) H. M. CUNNINGHAM and R. D.: Pontefranct, Nature 232, 332 (1971).

(8) G. H. KAY: J.A.W.W.A., 513 (september 1974).

(9) M. MAH and E. S. BOATMAN: Proc. Scanning Electr. Micr., vol. I, 85 (1978).

(10) R.W. BUELOW et al.: J.A.W.W.A., 72 (1980).

(11) E. S. BOATMAN, J.A.W.W.A., 74, 533 (1982)

(12) J. R. MILLETTE and E. F. McFARREN: Proc. Scanning Electr. Micr., vol. III, 451 (1976).

(13) J. R. MILLETTE, J. D. TWYMAN and E. C. HANSEN: Proc. Scanning Electr. Micr., vol. I, 579 (1979). 